\title{
Analysis of Government Budgeting for Health: Case Study of COVID-19 in East Java Province, Indonesia
}

\author{
Dewi Rokhmah $^{1 *}$, Ricko Pratama Ridzkyanto², Khoiron ${ }^{3}$
}

\begin{abstract}
${ }^{1}$ Department of Health Promotion and Behavior Science, Faculty of Public Health, University of Jember, Indonesia 2Department of Health Administration and Policy, Faculty of Public Health University of Jember, Indonesia

${ }^{3}$ Department of Environmental Health, Faculty of Public Health, University of Jember, Indonesia
\end{abstract}

\begin{abstract}
The COVID-19 in Indonesia was first reported in March 2, 2020 with two cases, and the number has increased each day until April 23, 2020 and reached 7,775 positive cases of COVID-19. East Java Province ranks the third in Indonesia with 662 cases. COVID-19 requires a health financing system aimed for COVID-19 patients and hospital services. The study aimed to describe the amount of COVID-19 and the use of funds for COVID-19 in East Java Province. This study applied descriptive analytic method. Secondary data analysis used the COVID-19 fund data of 31 districts/cities in East Java Province from the Regional Development Agency of East Java Province in period of March 23 - April 23, 2020. The results showed that the total budget for COVID-19 in the province was worth IDR 2,102,600,000,000 divided for Curative IDR 727,654,880,535, Promotive Preventive IDR 97,134,092,873, Social Safety Net IDR 877,301,513,766 and Recovery IDR 400,50,512,826. The total fund for COVID-19 per capita in the province was IDR1,997,139 divided for Curative IDR 691,158, Promotive Preventive IDR 92,262, Social Safety Net IDR 833,299 and Recovery IDR 380,421. According to districts, the highest budgeting is Jember District, Surabaya City, and Gresik District. The highest per-capita funds, according to districts/cities, are Batu City, Jember District, and Trenggalek District.
\end{abstract}

Keywords: COVID-19 pandemic, fund management, health financing

\section{Introduction}

In December 31, 2019, information began to spread about coronavirus caused by Coronavirus Disease 2019 (COVID-19). COVID-19 has been declared by WHO as the World Public Anxiety Emergency/Public Health Emergency of Pandemic, where transmission is very fast in humans with a quite high level of mortality rate. The Law Number 4 of 1984 concerning Communicable Disease Outbreaks stated that outbreaks means outbreaks of infectious diseases in a society where the number of patients significantly increases beyond normal conditions at certain times and regions and may cause a havoc. The Minister of Health determines certain types of diseases that can cause epidemics. The head of the National Agency for Disaster Management has decided the status of certain conditions in the Coronavirus Disease in Indonesia due to Coronavirus in Indonesia and then through the Decree of the Head of the National Disaster Management Agency No. 13 of 2020 concerning the Extension of the Status of Certain Conditions in the Disaster of the Corona Virus Disease in Indonesia, whereas the status of specific conditions is extended for

Correspondence*: Dewi Rokhmah, Health Promotion and Behavior Science, Faculty of Public Health, University of Jember, Kalimantan Street No. I / 93 68121 Jember, East Java, Indonesia, E-mail: dewirokhmah@unej.ac.id, Phone +62 812-1540-0530
91 days dated on February 29, 2020.1

The COVID-19 disease in Indonesia was first reported on March 2, 2020 in two cases and has increased each day until April 23, 2020 and reached 7,775 positive cases of COVID-19 consisting of 647 death cases, 960 recovery cases, and 6,168 active cases of treatment. East Java Province ranks the third in Indonesia with a total of 662 cases per April 23, 2020, consisting of 66 death cases, 127 recovery cases, and 469 active cases of treatment. Of the 469 active cases, 168 cases were treated at home, 31 cases were treated in the building, and 270 cases were treated in hospital. ${ }^{2}$

The COVID-19 financing aims to facilitate the payment of treated COVID-19 patients. It can be a reference for hospitals that provide services for COVID-19 to maintain the quality, efficient cost, and sustainability of health care services for COVID-19 patients. ${ }^{3}$ According to the Regulation of the President of the Republic of Indonesia Number 72 of 2012 Concerning the National Health System, the sources of health financing are the government, local government, the private sector, community organizations, and the community itself. 
Investment of public health care services are a public good, which is the responsibility of the government. In contrast, for individual health care services, the financing is private, except for the poor and the government's inability to be responsible. Adequate, integrated, stable, and sustainable health financing plays a vital role in the delivery of health care services to achieve health development goals. Health financing is provide to produce the availability of health budget with sufficient amount, be fairly allocated and utilized effectively and efficiently for the implementation of health efforts that are equitable, affordable, and quality for the whole community. ${ }^{4}$

Based on the explanation of the problem above and the theory presented, the study objective was to find a description of the COVID-19 fund and the use of funds for COVID-19 in East Java Province, Indonesia.

\section{Method}

This study was a descriptive-analytic study which aimed to determine the amount of COVID-19 funds and the use of COVID-19 funds in East Java Province, Indonesia. Secondary data analysis used COVID-19 fund data of 31 districts/cities in the East Java Province from the Regional Development Agency of East Java Province in period of March 23 - April 23, 2020. The analytical test used was a descriptive analysis using tables and nar- ratives reinforced with theoretical studies and related literature.

\section{Results}

Health financing comes from various sources, namely the government, local government, private sector, community organizations, and the community itself. Adequate, integrated, stable, and sustainable health financing plays a vital role in the delivery of health care services to achieve health development goals. ${ }^{11}$ This study discussed the government budget for COVID-19 as follows in Table 1 and Figure 1.

The study results showed at Table 1 that of 31 dis-
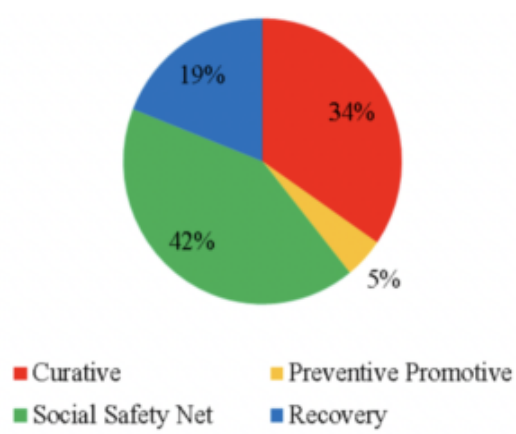

Figure 1. Allocation of Budget for COVID-19 in East Java Province, Indonesia

Table 1. Allocation of Budget for COVID-19 in East Java Province, Indonesia

\begin{tabular}{|c|c|c|c|c|c|}
\hline District/City & Curative (IDR) & Preventive-Promotive (IDR) & Social Safety Net (IDR) & Recovery (IDR) & Total Budget (IDR) \\
\hline Surabaya & $67,830,474,928$ & $9,054,638,164$ & $81,780,222,914$ & $37,334,663,994$ & $196,000,000,000$ \\
\hline Malang & $12,908,554,667$ & $1,723,153,079$ & $15,563,277,116$ & $7,105,015,138$ & $37,300,000,000$ \\
\hline Jember & $138,429,540,671$ & $18,478,853,395$ & $166,898,414,109$ & $76,193,191,825$ & $400,000,000,000$ \\
\hline Sidoarjo & $39,452,419,091$ & $5,266,473,218$ & $47,566,048,021$ & $21,715,059,670$ & $114,000,000,000$ \\
\hline Pasuruan & $26,647,686,579$ & $3,557,179,279$ & $32,127,944,716$ & $14,667,189,426$ & $77,000,000,000$ \\
\hline Banyuwangi & $7,267,550,885$ & $970,139,803$ & $8,762,166,741$ & $4,000,142,571$ & $21,000,000,000$ \\
\hline Kediri & $7,025,299,189$ & $937,801,810$ & $8,470,094,516$ & $3,866,804,485$ & $20,300,000,000$ \\
\hline Gresik & $51,911,077,752$ & $6,929,570,023$ & $62,586,905,291$ & $28,572,446,934$ & $150,000,000,000$ \\
\hline Jombang & $26,993,760,431$ & $3,603,376,412$ & $32,545,190,751$ & $14,857,672,406$ & $78,000,000,000$ \\
\hline Bojonegoro & $26,647,686,579$ & $3,557,179,279$ & $32,127,944,716$ & $14,667,189,426$ & $77,000,000,000$ \\
\hline Lamongan & $12,458,658,660$ & $1,663,096,806$ & $15,020,857,270$ & $6,857,387,264$ & $36,000,000,000$ \\
\hline Tuban & $20,764,431,101$ & $2,771,828,009$ & $25,034,762,116$ & $11,428,978,774$ & $60,000,000,000$ \\
\hline Probolinggo & $42,221,009,904$ & $5,636,050,286$ & $50,904,016,303$ & $23,238,923,507$ & $122,000,000,000$ \\
\hline Blitar & $35,991,680,575$ & $4,804,501,883$ & $43,393,587,668$ & $19,810,229,874$ & $104,000,000,000$ \\
\hline Mojokerto & $7,267,550,885$ & $970,139,803$ & $8,762,166,741$ & $4,000,142,571$ & $21,000,000,000$ \\
\hline Sumenep & $8,651,846,292$ & $1,154,928,337$ & $10,431,150,882$ & $4,762,074,489$ & $25,000,000,000$ \\
\hline Nganjuk & $6,679,225,337$ & $891,604,676$ & $8,052,848,481$ & $3,676,321,506$ & $19,300,000,000$ \\
\hline Lumajang & $4,568,174,842$ & $609,802,162$ & $5,507,647,666$ & $2,514,375,330$ & $13,200,000,000$ \\
\hline Tulungagung & $622,932,934$ & $83,154,840$ & $751,042,863$ & $342,869,363$ & $1,800,000,000$ \\
\hline Bangkalan & $17,303,692,584$ & $2,309,856,674$ & $20,862,301,764$ & $9,524,148,978$ & $50,000,000,000$ \\
\hline Bondowoso & $15,919,397,177$ & $2,125,068,140$ & $19,193,317,623$ & $8,762,217,060$ & $46,000,000,000$ \\
\hline Madiun & $13,842,954,067$ & $1,847,885,340$ & $16,689,841,411$ & $7,619,319,182$ & $40,000,000,000$ \\
\hline Magetan & $12,458,658,660$ & $1,663,096,806$ & $15,020,857,270$ & $6,857,387,264$ & $36,000,000,000$ \\
\hline Ngawi & $1,626,547,103$ & $217,126,527$ & $1,961,056,366$ & $895,270,004$ & $4,700,000,000$ \\
\hline Pacitan & $3,460,738,516$ & $461,971,335$ & $4,172,460,353$ & $1,904,829,796$ & $10,000,000,000$ \\
\hline Pamekasan & $21,456,578,804$ & $2,864,222,276$ & $25,869,254,187$ & $11,809,944,733$ & $62,000,000,000$ \\
\hline Ponorogo & $10,728,289,403$ & $1,432,111,138$ & $12,934,627,093$ & $5,904,972,366$ & $31,000,000,000$ \\
\hline Sampang & $7,613,624,737$ & $1,016,336,937$ & $9,179,412,776$ & $4,190,625,550$ & $22,000,000,000$ \\
\hline Situbondo & $8,997,920,143$ & $1,201,125,471$ & $10,848,396,917$ & $4,952,557,469$ & $26,000,000,000$ \\
\hline Trenggalek & $34,607,385,168$ & $4,619,713,349$ & $41,724,603,527$ & $19,048,297,956$ & $100,000,000,000$ \\
\hline Batu & $35,299,532,871$ & $4,712,107,616$ & $42,559,095,598$ & $19,429,263,915$ & $102,000,000,000$ \\
\hline Total & $727,654,880,535$ & $97,134,092,873$ & $877,301,513,766$ & $400,509,512,826$ & $2,102,600,000,000$ \\
\hline
\end{tabular}


Table 2. Distribution of COVID-19 Mitigation Funds per Capita in East Java Province, Indonesia

\begin{tabular}{|c|c|c|c|}
\hline District/City & Total of Population (People) & Fund (IDR) & Fund per Capita (IDR) \\
\hline Surabaya & $2,904,751$ & $196,000,000,000$ & 67,476 \\
\hline Malang & $2,619,975$ & $37,300,000,000$ & 14,237 \\
\hline Jember & $2,459,890$ & $400,000,000,000$ & 162,609 \\
\hline Sidoarjo & $2,282,215$ & $114,000,000,000$ & 49,951 \\
\hline Pasuruan & $1,637,682$ & $77,000,000,000$ & 47,018 \\
\hline Banyuwangi & $1,617,814$ & $21,000,000,000$ & 12,980 \\
\hline Kediri & $1,580,092$ & $20,300,000,000$ & 12,847 \\
\hline Gresik & $1,326,420$ & $150,000,000,000$ & 113,086 \\
\hline Jombang & $1,268,504$ & $78,000,000,000$ & 61,490 \\
\hline Bojonegoro & $1,252,020$ & $7,000,000,000$ & 61,501 \\
\hline Lamongan & $1,189,380$ & $36,000,000,000$ & 30,268 \\
\hline Tuban & $1,177,016$ & $60,000,000,000$ & 50,976 \\
\hline Probolinggo & $1,174,890$ & $122,000,000,000$ & 103,840 \\
\hline Blitar & $1,163,789$ & $104,000,000,000$ & 89,363 \\
\hline Mojokerto & $1,126,392$ & $21,000,000,000$ & 18,644 \\
\hline Sumenep & $1,092,387$ & $25,000,000,000$ & 22,886 \\
\hline Nganjuk & $1,057,011$ & $19,300,000,000$ & 18,259 \\
\hline Lumajang & $1,044,718$ & $13,200,000,000$ & 12,635 \\
\hline Tulungagung & $1,043,182$ & $1,800,000,000$ & 1,725 \\
\hline Bangkalan & 994,212 & $50,000,000,000$ & 50,291 \\
\hline Bondowoso & 778,789 & $46,000,000,000$ & 59,066 \\
\hline Madiun & 683,784 & $40,000,000,000$ & 58,498 \\
\hline Magetan & 629,020 & $36,000,000,000$ & 57,232 \\
\hline Ngawi & 830,134 & $4,700,000,000$ & 5,662 \\
\hline Pacitan & 555,984 & $10,000,000,000$ & 17,986 \\
\hline Pamekasan & 888,214 & $62,000,000,000$ & 69,803 \\
\hline Ponorogo & 871,825 & $31,000,000,000$ & 35,558 \\
\hline Sampang & 989,001 & $22,000,000,000$ & 22,245 \\
\hline Situbondo & 685,776 & $26,000,000,000$ & 37,913 \\
\hline Trenggalek & 697,600 & $100,000,000,000$ & 143,349 \\
\hline Batu & 209,125 & $102,000,000,000$ & 487,747 \\
\hline Total & $37,831,592$ & $2,102,600,000,000$ & $1,997,139$ \\
\hline
\end{tabular}

tricts/cities in the East Java Province, the top highest Total Budget for COVID-19 by districts/cities were Jember District with IDR 400 billion, Surabaya City with IDR 196 billion, and Gresik District with IDR 150 billion. Total Budget worth IDR 400 billion in Jember District was allocated for Curative IDR 138,429,540,671, Promotive-Preventive IDR 18,478,853,395, Social Safety Net IDR $166,898,414,109$, and Recovery IDR 76,193,191,825. A total fund of IDR 196 billion in Surabaya City was allocated for Curative IDR 67,830,474,928, Promotive Preventive IDR 9,054,638,164, Social Safety Net IDR 81,780,222,914, and Recovery IDR 37,334,663,994. Funds in the amount of IDR 150 billion in Gresik District were allocated for Curative IDR 51,911,077,752, Promotive Preventive IDR 6,929,570,023, Social Safety Net IDR 62,586,905,291 and Recovery IDR $28,572,446,934$.

The results of the study on Table 2 showed that of the 31 districts/cities in East Java Province, the highest Fund per Capita by districts/cities were Batu City with IDR 487,747, Jember District with IDR 162,609, and Trenggalek District with IDR 143,349. Based on Table 3, Total Fund per Capita worth IDR 487,747 in Batu City were allocated for Curative IDR 168,796, Promotive

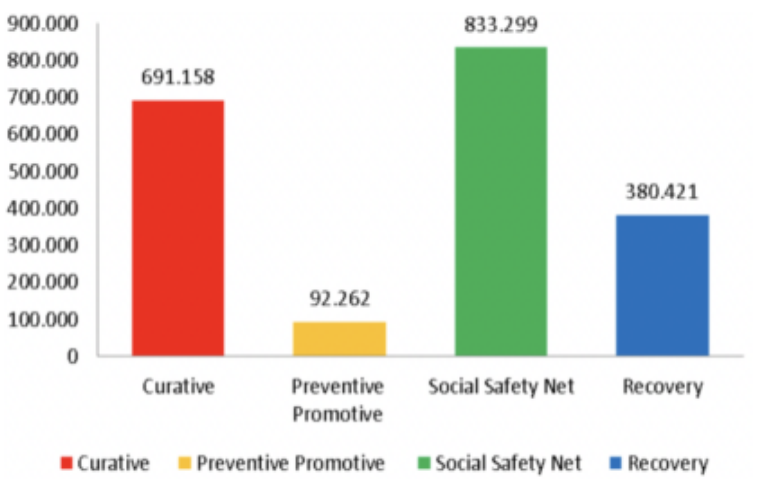

Figure 2. Distribution of the Use of COVID-19 Mitigation Funds per Capita in East Java Province, Indonesia

Preventive IDR 22,532, Social Safety Net IDR 203,510, and Recovery IDR 92,907. Fund per capita worth IDR 162,609 in Jember District were allocated for Curative IDR 56,275, Promotive Preventive IDR 7,512, Social Safety Net IDR 67,848 and Recovery IDR 30,974. The Per-capita funds worth IDR 143,349 in Trenggalek District were allocated for Curative IDR 49,609, Promotive Preventive IDR 6,622, Social Safety Net IDR 59,812, and Recovery IDR 27,305. 
Table 3. Distribution of Utilization of Covid 19 Mitigation Funds per Capita in East Java Province, Indonesia

\begin{tabular}{|c|c|c|c|c|c|}
\hline District/City & Curative (IDR) & Preventive-Promotive (IDR) & Social Safety Net (IDR) & Recovery (IDR) & Total of Funds per Capita (IDR) \\
\hline Surabaya & 23,352 & 3,117 & 28,154 & 12,853 & 67,476 \\
\hline Malang & 4,927 & 658 & 5,940 & 2,712 & 14,237 \\
\hline Jember & 56,275 & 7,512 & 67,848 & 30,974 & 162,609 \\
\hline Sidoarjo & 17,287 & 2,308 & 20,842 & 9,515 & 49,951 \\
\hline Pasuruan & 16,272 & 2,172 & 19,618 & 8,956 & 47,018 \\
\hline Banyuwangi & 4,492 & 600 & 5,416 & 2,473 & 12,980 \\
\hline Kediri & 4,446 & 594 & 5,361 & 2,447 & 12,847 \\
\hline Gresik & 39,136 & 5,224 & 47,185 & 21,541 & 113,086 \\
\hline Jombang & 21,280 & 2,841 & 25,656 & 11,713 & 61,490 \\
\hline Bojonegoro & 21,284 & 2,841 & 25,661 & 11,715 & 61,501 \\
\hline Lamongan & 10,475 & 1,398 & 12,629 & 5,766 & 30,268 \\
\hline Tuban & 17,642 & 2,355 & 21,270 & 9,710 & 50,976 \\
\hline Probolinggo & 35,936 & 4,797 & 43,327 & 19,780 & 103,840 \\
\hline Blitar & 30,926 & 4,128 & 37,286 & 17,022 & 89,363 \\
\hline Mojokerto & 6,452 & 861 & 7,779 & 3,551 & 18,644 \\
\hline Sumenep & 7,920 & 1,057 & 9,549 & 4,359 & 22,886 \\
\hline Nganjuk & 6,319 & 844 & 7,619 & 3,478 & 18,259 \\
\hline Lumajang & 4,373 & 584 & 5,272 & 2,407 & 12,635 \\
\hline Tulungagung & 597 & 80 & 720 & 329 & 1,725 \\
\hline Bangkalan & 17,404 & 2,323 & 20,984 & 9,580 & 50,291 \\
\hline Bondowoso & 20,441 & 2,729 & 24,645 & 11,251 & 59,066 \\
\hline Madiun & 20,245 & 2,702 & 24,408 & 11,143 & 58,498 \\
\hline Magetan & 19,806 & 2,644 & 23,880 & 10,902 & 57,232 \\
\hline Ngawi & 1,959 & 262 & 2,362 & 1,078 & 5,662 \\
\hline Pacitan & 6,225 & 831 & 7,505 & 3,426 & 17,986 \\
\hline Pamekasan & 24,157 & 3,225 & 29,125 & 13,296 & 69,803 \\
\hline Ponorogo & 12,306 & 1,643 & 14,836 & 6,773 & 35,558 \\
\hline Sampang & 7,698 & 1,028 & 9,281 & 4,237 & 22,245 \\
\hline Situbondo & 13,121 & 1,751 & 15,819 & 7,222 & 37,913 \\
\hline Trenggalek & 49,609 & 6,622 & 59,812 & 27,305 & 143,349 \\
\hline Batu & 168,796 & 22,532 & 203,510 & 92,907 & 487,747 \\
\hline Total & 691,158 & 92,262 & 833,299 & 380,421 & $1,997,139$ \\
\hline
\end{tabular}

\section{Discussion}

The COVID-19 outbreak has designated under the National Agency for Disaster Management Authority. ${ }^{1}$ The Ministry of Finance framework needs to understand the nature and scale of these impacts and their relevance to financial, economic, and fiscal management strategies and policies for which the government has primary responsibility. ${ }^{5}$ Based on the Law Number 24 of 2007 Concerning Disaster Management, one of the government's tasks is to grant the rights of people affected by the disaster. The Law stated that one of reasons for people affected by an emergency is to get health care services. ${ }^{6}$ The health care service process cannot separate from health financing. Health costs are a large number of funds required to organize and utilize various health efforts needed by individuals, families, groups, and communities. ${ }^{7}$ The purpose of implementing the health financing subsystem is the availability of adequate health funds, allocated relatively, evenly, and utilized effectively and efficiently, channeled according to its designation to ensure the implementation of health development to improve the highest degree of public health. ${ }^{3}$ Planning and arranging adequate health care financing can help the government be able to mobilize sources of health financing, allocate it rationally, and use it efficiently and effectively.
Health financing in each region is different. ${ }^{7}$ Health budgeting is due to several factors, such as the ability of regional planning, regional commitment, advocacy ability, when prioritizing local health problems, and program interventions. ${ }^{8}$ The distribution of the use of COVID-19 Prevention Funds consisted of curative funds for treatment, promotive-preventive for promotional and prevention activities, social safety net funds to protect informal and daily workers during the COVID-19 pandemic, and recovery funds to restore the condition of the community and the environment affected by the disaster. Based on the Ministry of Social Affairs' understanding, the social safety net as the form of support from the Ministry of Social Affairs reduces the burden on the poor and vulnerable families. ${ }^{9}$ The Social Safety Net has previously been conducted in several countries and is effective. ${ }^{10}$ Therefore, Social Safety Net occupies the highest budget from the distribution of COVID-19 funds. The Curative sector ranked the second and followed by Recovery sector. Promotive-Preventive is at the lowest order of financing. Based on data from the Ministry of Health regarding the growing number of COVID-19 patients, this causes Curative funds to be higher than funds for PromotivePreventive. Patients that can make claims are those with People-in-Monitoring (PIM) status, both the PIM aged 
over 60 years with or without comorbidities and the PIM aged less than 60 years with comorbidities; Patient under Supervision (PUS), those with COVID-19 confirmation; valid for Indonesian citizens and foreign citizens treated at hospitals in the territory of the Republic of Indonesia. Service areas include outpatient and inpatient care at referral hospitals for handling certain emerging infectious diseases and other hospitals that provide services for COVID-19 patients. ${ }^{4}$ Services that can be funded follow the service standards in the patient-handling guidelines based on the patient's medical needs as well as financing for outpatient and inpatient services including administration of facilities, accommodation (rooms and assistance in emergency rooms, inpatients, intensive care rooms, and room isolation), doctor's services, actions in the place, the use of ventilators, medical consumables, diagnostic support examinations (laboratory and radiology following medical indications), drugs, medical devices including the use of personal protective equipment in the room, referral, corpse screening, and other health care services according to medical indications. ${ }^{4}$

Payment methods are based on services provided and a maximum length of treatment is determined usingIndonesian Case-Based Groups (INA-CBG) rates and top-up procedures calculated as an effective and efficient cost per day. The amount of the INA-CBG tariff for COVID-19-related outpatient services uses regional class A hospital rate 1 . The amount of INA-CBG fare for COVID-19-related inpatient services uses local A class 1 hospital rates and class 3 Nursing Classes. Make a referral to COVID-19 to other hospitals (referral hospitals and other hospitals that provide COVID-19 services). The price of the INA-CBG tariff follows the payment norm, e.g., caring for 6 hours, paying INA-CBG outpatient rates, caring for $>6$ hours- 2 today, $70 \%$ of the fare paid claims, caring for $>2-5$ days, $80 \%$ of the menu paid claims, caring for $>5$ days, paid $100 \%$ of the claims rates. 4 Top up per day (cost per day) includes components of services administration, accommodation in inpatient rooms, doctor services, outpatient and inpatient services, diagnostic supporting examinations (laboratory and radiological according to medical indications), medicines, medical devices, and consumable restorative materials such as personal protective equipment (PPE), ambulance reference, and corpse screening. For hospitals that receive PPE assistance and medicines from the government, deductions made from claims received. The PPE and medicines purchased by the hospital must attach a purchase invoice and assistance from other sources. The COVID-19 patients who get recovered (return status) with evidence of laboratory examinations (by the COVID-19 prevention and control manual), for concomitant diseases that still require treatment, the benefits of the next service are changed to the National Health
Insurance (NHI) service and general services.

\section{Conclusion}

The total budget for COVID-19 in East Java Province is IDR 2,102,600,000,000 allocated for Curative IDR 727,654,880,535, Promotive-Preventive IDR 97,134,092,873, Social Safety Net IDR $877,301,513,766$, and Recovery IDR 727,654,880,535, Promotive Preventive IDR 97,134,092,873, Social Safety Net IDR 877,301,513,766, and Recovery IDR 727,654,880,535, Promotional-Preventive IDR 97,134,092,873, Social Safety Net IDR $877,301,513,766$, and Recovery IDR $727,654,880,535$ IDR $400,509,512,826$. The highest total of coping funds by districts/cities are Jember with IDR 400 billion, Surabaya City with IDR 196 billion, and Gresik District with IDR 150 billion.

The total per-capita funds for COVID-19 in East Java Province is IDR 1,997,139 allocated for Curative IDR 691,158, Promotive-Preventive IDR 92,262, Social Safety Net IDR 833,299 and Recovery IDR 380,421. The highest total per-capita funds by districts/cities are Batu City with IDR 487,747 , Jember District with IDR 162,609 and Trenggalek District with IDR 143,349.

\begin{abstract}
Abbreviations
COVID-19: Coronavirus Disease 2019; PIM: People-in-Monitoring; PUS: People Under Supervision; PPE: Personal Protective Equipment, INA-CBG: Indonesian Case-Based Groups; NHI: National Health Insurance.
\end{abstract}

\section{Ethics Approval and Consent to Participate}

Not Applicable

\section{Competing Interest}

Authors declare that they have no competing interests to disclose.

\section{Availability of Data and Materials}

The authors have full access to all the data in the study and take responsibility for the data integrity.

\begin{abstract}
Authors' Contribution
Dewi Rokhmah, Ricko Pratama Ridzkyanto, Khoiron designed and conceptualized the study. Dewi Rokhmah and Khoiron collected data. Ricko Pratama Ridzkyanto analyzed data. Dewi Rokhmah, Ricko Pratama Ridzkyanto, Khoiron discussed and interpreted the final results. Ricko Pratama Ridzkyanto wrote the first draft of the manuscript. Dewi Rokhmah, Ricko Pratama Ridzkyanto, Khoiron revised and contributed to the final manuscript.
\end{abstract}

\section{Acknowledgment}

The researcher would like to thank the Regional Development Agency of East Java Province for granting a permission to carry out this study. 
Rokhmah et al, Analysis of Government Budgeting for Health: Case Study of COVID-19 in East Java Province, Indonesia

\section{References}

1. Arifin D. Presiden tetapkan COVID-19 sebagai bencana nasional; 2020 [cited 2020 April 20].

2. Gugus Tugas Pusat covid19.go.id. Peta sebaran COVID-19 JATIM; 2020 [cited 2020 April 22].

3. Presiden Republik Indonesia. Undang-undang Nomor 24 tahun 2007 Tentang Penganggulangan Bencana; [updated 2007 April 26; cited 2020 May 10].

4. Kementerian Kesehatan. Keputusan Menteri Kesehatan Republik Indonesia Nomor Hk.01.07/Menkes/238/2020 Tentang Petunjuk Teknis Klaim Penggantian Biaya Perawatan Pasien Penyakit Infeksi Emerging Tertentu Bagi Rumah Sakit Yang Menyelenggarakan Pelayanan Coronavirus Disease 2019; 2020.

5. OECD. Disaster risk financing: a global survey of practices and challenges. OECD Publishing: Paris; 2015.
6. Presiden Republik Indonesia. Undang-undang Nomor 24 tahun 2007 Tentang Penganggulangan Bencana; [updated 2007 April 26; cited 2020 May 10].

7. Setyawan FEB. Sistem Pembiayaan Kesehatan. Saintika Medika. 2017; 11 (2): 119

8. Harmana WA. Faktor-faktor yang mempengaruhi pembiayaan kesehatan daerah bersumber anggaran pendapatan dan belanja daerah tahun 2006. Jurnal Manajemen Pelayanan Kesehatan. 2006; 9(3).

9. Kementerian Sosial Republik Indonesia. Upaya Kemensos terkait pencegahan COVID-19; 2020 [cited 2020 April 20].

10. Alam MA, Hossain SA. Effectiveness of social safety net programs for poor people in the government level of Bangladesh. International Journal of Social Sciences and Management. 2016; 3 (3): 153-8.

11. Presiden Republik Indonesia. Peraturan Presiden 72 tahun 2012 tentang Sistem Kesehatan Nasional; 2012. 